\title{
Discussion of "Capital Market Equilibrium with Imperfect Competition: The Case of the ECB's Asset Purchase Programme" by Koziol/Neus
}

\author{
Andreas Löffler ${ }^{1}$ (D)
}

Received: 26 May 2020 / Accepted: 4 June 2020 / Published online: 16 June 2020

(C) The Author(s) 2020

\section{JEL-Classification D43 - G12}

The current Corona crisis makes us almost forget that about eight years ago a severe euro crisis shook the financial markets. It was Mario Draghi who, with his nowwinged word of "whatever it takes", made sure that market participants regained their confidence. However, it was not only the dictum that helped to strengthen the markets. Rather, the establishment of the Securities Markets Program, and later the asset purchase program (APP), had the effect of providing sufficient liquidity in the markets and achieving price stability.

Theoretical economists do not often deal with current political issues. For while it was understandable that the above-mentioned programs work in financial markets, details and effects on prices and market equilibrium are not so obvious. It is precisely these issues that are at the heart of Koziol and Neus' work.

It should be noted, and the authors also refer to this at the beginning of their introduction, that the results of the paper do not only refer to the ECB programs. Other cases of price-inelastic demand are also conceivable, such as stock repurchase programs or funds that strictly follow an asset savings plan. In this respect, this is not only a discussion of current political decision, but also a very basic theoretical question.

The authors make use of the tools that we regularly use in the financial sector. They model a multi-period exchange equilibrium in which market participants trade in a CAPM-like manner, but a market participant (more precisely the ECB) undertakes to buy government bonds or securities under all circumstances in order

A. Löffler

al@wacc.de

1 Freie Universität Berlin, Thielallee 73, 14195 Berlin, Germany 
to support the market. What are the effects of such price-inelastic demand at each stage of the equilibrium? How exactly does the adjustment price mechanism work?

Koziol and Neus decided to use a variant of CAPM that appears less in the textbooks. They model an exchange economy with imperfect competition (one can probably discuss for a longer time whether this is only a slightly modified CAPM as they frame it - it is in any case a CAPM that differs from the presentation by Sharpe and Mossin). And such a model is appropriate if the effects of ECB activity are not to disappear completely in equilibrium. One of the first papers in which imperfect competition is systematically investigated was developed by Kyle (1985, 1989). Its strongest deviation from the traditional CAPM, it seems to me, is the assumption that investors are no longer price takers but become part of the model with their demand functions. This changes the structure of the equilibrium. Whereas in the classical CAPM the Walrasian auctioneer "only" suggests a price which then immediately matches supply and demand, here we are actually dealing with a game theoretic model. One investor reacts to another investor and such a reaction does not exist in the classical CAPM, where all investors only accept the price that clears the market. One can see that Koziol and Neus have given a lot of thought to a meaningful modelling of the APP and have also chosen a suitable format for discussion. In my opinion, such models are being studied far too little.

This is again evident in the results achieved by both authors. The most important result in my view was that late purchases by the ECB imply a stronger price increase than early trades of the same size. At first glance, one might think that timing is not important at all, but Koziol and Neus show that this is not the case and they also refer to an intuition, which helps one to understand this result: It is the strategic interaction induced by imperfect competition that causes the liquidity to decrease over time which in turn implies a stronger price effect of late trades by the ECB.

The analysis of Koziol and Neus, which the authors write very clearly in their introduction, is a partial model. In reality, the ECB is an institution which returns its profits to the Member States and thus to the investors themselves. It is not obvious whether in a model in which this retroactivity exists the results achieved so far will be maintained. A next, obvious step is now to examine what happens in such a total model—does the timing of the buy-back program also play a role here? It is not at all clear whether the present model is suitable for this question or whether it will have to be extended again, complicating matters further.

Koziol and Neus have shown interesting results with their work on the ECB, thus initiating an important discussion which should now be continued. Theoretical work on financing has become rather rare today, and theoretical work dealing with political issues even rarer. For this reason alone, their paper deserves considerable attention.

Funding Open Access funding provided by Projekt DEAL.

Open Access This article is licensed under a Creative Commons Attribution 4.0 International License, which permits use, sharing, adaptation, distribution and reproduction in any medium or format, as long as you give appropriate credit to the original author(s) and the source, provide a link to the Creative Commons licence, and indicate if changes were made. The images or other third party material in this article are included in the article's Creative Commons licence, unless indicated otherwise in a credit line to the material. If material is not included in the article's Creative Commons licence and your intended use is not 
permitted by statutory regulation or exceeds the permitted use, you will need to obtain permission directly from the copyright holder. To view a copy of this licence, visit http://creativecommons.org/licenses/by/4. $0 \%$

\section{Literatur}

Kyle, A. S. 1985. Continuous auctions and insider trading. Econometrica 53:1315-1335.

Kyle, A.S. 1989. Informed speculation with imperfect competition. Review of Economic Studies 56:317-356. 